\title{
Cosimo Amantonico, Metodo e poesia in Mallarmé
}

\section{Ida Merello}

\section{(2) OpenEdition}

\section{Journals}

\section{Edizione digitale}

URL: http://journals.openedition.org/studifrancesi/6055

DOI: 10.4000/studifrancesi.6055

ISSN: 2427-5856

\section{Editore}

Rosenberg \& Sellier

\section{Edizione cartacea}

Data di pubblicazione: 1 mai 2011

Paginazione: 201

ISSN: 0039-2944

\section{Notizia bibliografica digitale}

Ida Merello, «Cosimo Amantonico, Metodo e poesia in Mallarmé», Studi Francesi [Online], 163 (LV | I) |

2011, online dal 30 mai 2015, consultato il 13 janvier 2021. URL: http://journals.openedition.org/ studifrancesi/6055 ; DOI: https://doi.org/10.4000/studifrancesi.6055

Questo documento è stato generato automaticamente il 13 janvier 2021.

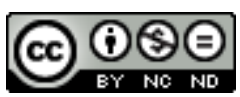

Studi Francesi è distribuita con Licenza Creative Commons Attribuzione - Non commerciale - Non opere derivate 4.0 Internazionale. 


\title{
Cosimo Amantonico, Metodo e poesia in Mallarmé
}

\author{
Ida Merello
}

NOTIZIA

cosimo Amantonico, Metodo e poesia in Mallarmé, Bari, Graphis, 2009, pp. 327.

1 Traversata filosofica del poeta, dove l'A. riflette sull'hegelismo di Mallarmé, indagandone l'ibridazione con possibili venature di positivismo e ripercorrendo l'evoluzione del suo pensiero nella corrispondenza e nei saggi teorici. A ogni affermazione del poeta l'A. fa corrispondere passi di Hegel ritenuti consonanti; mentre analogie poetiche sono colte invece nel Vathek di Beckford. L'A. vede una straordinaria coerenza teorica in ogni fase della produzione, che viene metodicamente ripercorsa attraverso esempi di analisi. 